\title{
A REVIEW ON SOME PASSIVE TECHNIQUES OF HEAT TRANSFER ENHANCEMENT USING INSERTS
}

\author{
Ninad Patil 1, Madhukar Tandale 2 \\ 1, 2 Dr.BabasahebAmbedkar Technological University, Lonere, India \\ Email: 1 patilninad.91@gmail.com
}

\begin{abstract}
Heat Transfer Enhancement Techniques are commonly used nowadays in all Thermal industries, where there is heat transfer in the thermal system. Number of new techniques were discovered and studied by various researchers for heat transfer augmentation including both active and passive methods. But emphasis was given for passive techniques of heat transfer enhancement as they directly affect operating cost. The most widely used passive techniques like twisted tape inserts, wire coil insert and conical inserts are focused in this paper. One of the aims of studying various heat transfer enhancement techniques is to assess the effect of an inherent conditions on heat transfer and recommend most effective technique for laminar \& turbulent flows. One of the conclusions of the study is twisted tape inserts are better for laminar flow \& conical inserts will be more suitable for turbulent region.
\end{abstract}

Key words: Heat transfer enhancement, passive techniques, twisted tape, wire coil inserts, conical inserts

\section{INTRODUCTION}

The economy of any thermal system mainly depends on efficiency of the Heat Exchangers used in it. The efficiency of Heat Exchanger can be raised by using appropriate method of heat transfer enhancement. The method used for heat transfer enhancement should satisfy the condition of maximum heat transfer and minimum pressure drop.

The heat transfer rate can be improved by introducing a disturbance in the fluid flow (breaking the viscous and thermal boundary layers), but in the process pumping power may increase significantly and ultimately the pumping cost becomes high. Therefore, to achieve a desired heat transfer rate in an existing heat exchanger at an economic pumping power may increase significantly and ultimately the pumping cost becomes high. Therefore to achieve a desired heat transfer rate in an existing heat exchanger at an economic pumping power, several techniques have been proposed continuously over the period of time. Some of the passive techniques using inserts are studied in this paper.

\section{LITERATURE REVIEW}

Enhancement of heat transfer generally means the increase in heat transfer rate with maintaining minimum pressure drop. Basically the single phase convective heat transfer can be enhanced by one of the following three methods:

1) Reducing the thermal boundary layer thickness

2) Increasing the disturbance in the fluid

3) Promoting the mixing of different portions of the fluids.

\section{A. Twisted Tape Insert}

Twisted tape insert is the most widely used swirl flow device for single-phase flows. It is a metallic strip or rod which is spirally or helically twisted permanently. Twisted tape generates a spiral flow along the tube length which gives better fluid mixing. These inserts increase the heat transfer coefficient significantly with a relatively small pressure drop penalty as reported by Smithberg and Landis (1), Lopina and Bergles (2), Date and Singham (3), Manglik and Bergles (4). that the short length twisted tapes perform better than the full length twisted tapes because the swirl generated by the short length twisted tape decays slowly downstream which increases the heat transfer coefficient with minimum pressure drop Use of twisted tapes for augmentation can be dated back to as early as up to the end of nineteenth century. One of the early researches on heat transfer enhancement by means of twisted tapes was carried out by Whitman (5). Saha et al. (6). 


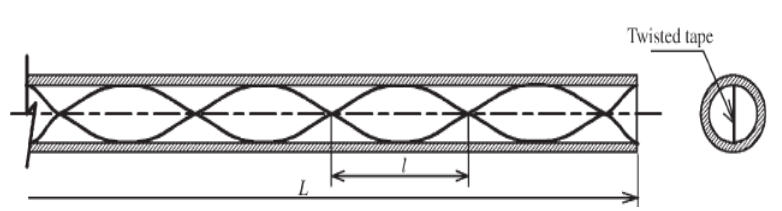

Fig. 1. Typical twisted tape

Promvonge (7) studied experimentally the effect of twisted tape insert on heat transfer and friction factor characteristics in concentric tube heat exchanger for Reynolds number 2000 to 12000 . He found that enhancement efficiency and Nusselt number increases with decreasing the twist ratio and friction factor also increase with decreasing the twist ratio.

\section{B. Wire Coil Insert}

Prasad and Shen (8) studied performance evaluation of several wire coil inserts in augmentation of convective heat transfer by using exergy analysis. They concluded that this method of enhancement is effective and acceptable from the view point of improving heat transfer and more effective at lower Reynolds numbers in comparison to higher Reynolds numbers.

Garcia et al. (9) studied experimentally Helical-wirecoils fitted inside a round tube in order to characterize their thermo hydraulic behavior in laminar, transition and turbulent flow. They found that in turbulent flow wire coils increase pressure drop up to nine times and heat transfer up to four times compared to the empty smooth tube. Garcia et al. (10) found performance comparison between wire coils and twisted tape inserts has shown that wire inserts perform better than twisted tapes in the low Reynolds number range: $\mathrm{Re}=700-2500$.

Gunes et al. (11) experimentally investigated the heat transfer and pressure drop in a coiled wire inserted tube in turbulent flow regime. They found that the Nusselt number rises with the increase of Reynolds number and wire thickness and the decrease of pitch ratio. He stated that the best operating regime of all coiled wire inserts is detected at low Reynolds number, leading to more compact heat exchanger.

Gunes et al. (12) investigated heat transfer and pressure drop in a tube with coiled wire inserts placed separately from the tube wall in turbulent flow regime. The Nusselt number and friction factor increase with decreasing pitch ratio (P/D) and distance (s) for coiled wire inserts.

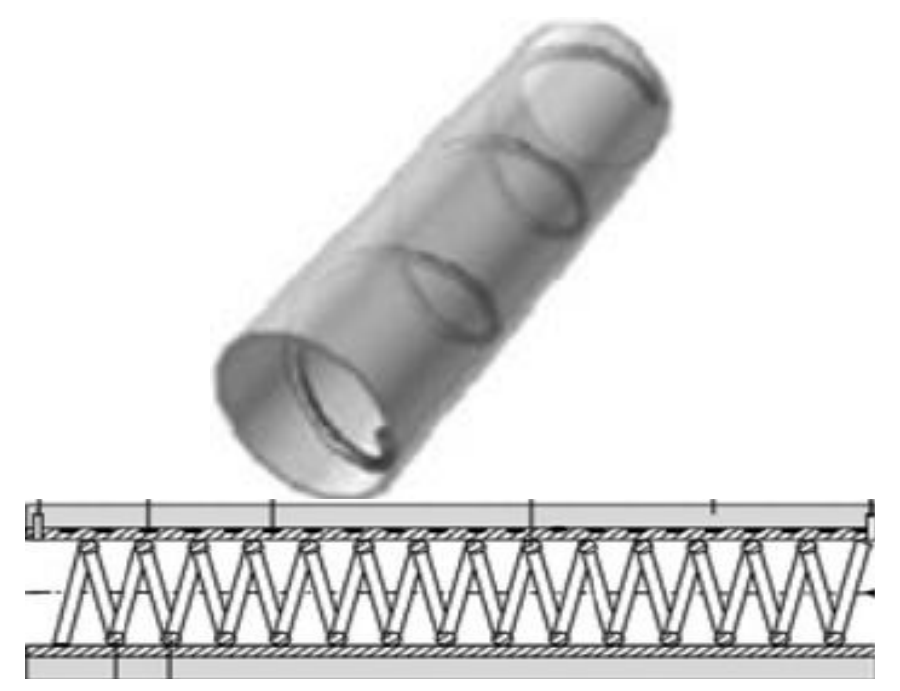

Fig. 2. Coiled Wire Turbulator

Naphon (13) investigated the heat transfer characteristics and the pressure drop of the horizontal double pipe with coil-wire insert. He stated that Effect of coil-wire insert on the enhancement of heat transfer tends to decrease as Reynolds number increases.

Garcia et al. (14) analyzed the thermohydraulic behaviour of three types of enhancement techniques corrugated tubes, dimpled tubes and wire coils. They concluded that that for Reynolds numbers lower than 200 , the use of smooth tubes is recommended. For Reynolds numbers between 200 and 2000, the employment of wire coils is more advantageous, while for Reynolds numbers higher than 2000; the use of corrugated and dimpled tubes is favoured over the wire coils because of the lower pressure drop encountered for similar heat transfer coefficient levels.

\section{Conical Inserts}

Promvonge and Eiamsa-ard (15) experimentally investigated the enhancements of heat transfer characteristics in a uniform heat flux circular tube fitted with conical nozzles and swirl generator. They found that found that each application of the conical nozzle and the snail can help to increase considerably the heat transfer rate over that of the plain tube by about $278 \%$ and $206 \%$ respectively. The use of the conical nozzle in common with the snail leads to a maximum heat transfer rate that 
is up by $316 \%$. But the increase in pressure drop is much higher than the increase in Nusselt number at the same Reynolds number.

You et al. (16) investigated thermo-hydraulic performance of conical strip inserts in laminar flow. He found that that the average Nusselt number of enhanced tube is augmented by $3.70-5.51$ times (average $\mathrm{Nu}=$ 16.15-24.05) while the average friction factor increases by $5.31-14.77$ times (average $f=0.59-1.51$ ) those of plain tube. The values of performance evaluation criterion (PEC) range between 1.17 and 2.97 .

Guo et al. (17) experimentally investigated Effects of reducing the upwind area of conical-strip tube inserts on heat transfer and friction factor characteristics of turbulent flow. They found that smaller pitch leads to higher heat transfer rate whereas the flow resistance is increased. A moderate pitch between conical strip is beneficial to the overall thermo-hydraulic performance.

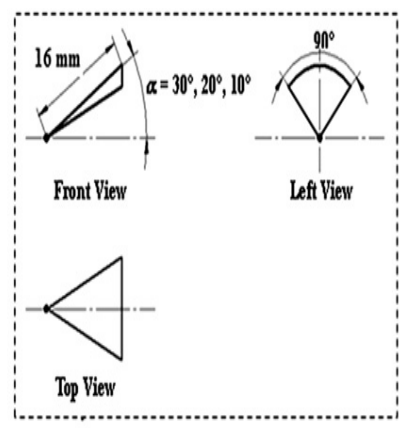

a

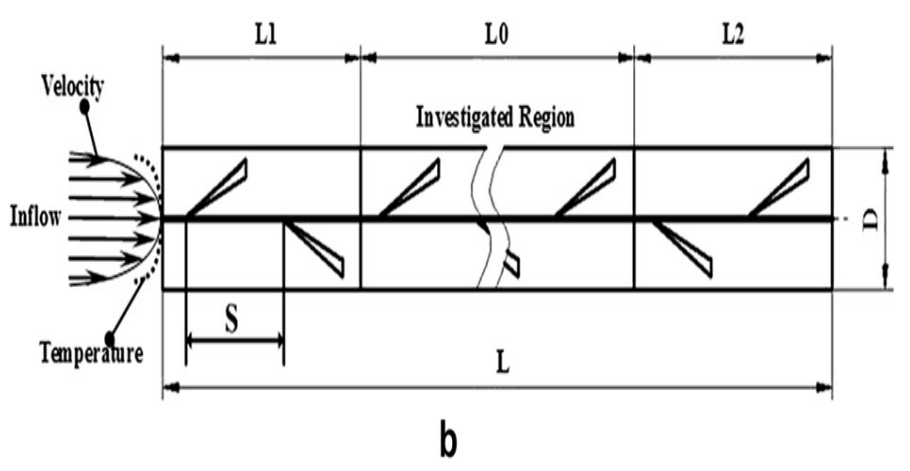

Fig. 3. (a) Geometry of the Conical Strip Insert, and (b) Schematic of a Circular Tube fitted with Conical Strip Inserts
Muthusamy et al. (18) investigated Heat transfer, friction factor and thermal performance factor characteristics in a circular tube fitted with conical cut-out turbulator integrated with internal fins for three pitch ratios (PR) 3, 4, 5 and tested with two different arrangements as convergent mode (C-turbulators) and divergent mode(D-turbulators).They found that the D-turbulators arrangement with turbulators) and divergent mode(Dturbulators). They found that the D-turbulators arrangement with $\mathrm{PR}=3$ shows the maximum heat transfer rate of $315 \%$, thermal performance factor of 2.4 and friction factor of 3.2 times than that of plain tube.

\section{RESEARCH METHODOLOGY}

\section{A. Test section and apparatus}

The all experiments were carried out in an open-loop experimental facility as similar as set up shown in Figure 4. It consists of a centrifugal blower, flow control valve, Venturimeter, an entry section, test section, and an exit section. The dimensions of tube are $41.3 \mathrm{~mm}$ inside diameter, $44.3 \mathrm{~mm}$ outside diameter, $1000 \mathrm{~mm}$ length and are constructed from Copper material of $1.5 \mathrm{~mm}$ thickness.

To provide uniform heat flux, flexible electric heater of size $10 \mathrm{~m}$ length and capacity of $1300 \mathrm{~W}$ is used. The Heater is simply wound around the whole periphery of the copper test tube at the pitch of 2 to $4 \mathrm{~mm}$. End connections of the flexible electric heater are directly coupled with the transformer probe from which the electric supply is given.

The entry section of the tube is connected to a P.P pipe provided with venturimeter via circular reducer piece. The air flow rate through the test unit has been regulated with the help of a control valve installed at the inlet of the blower. A $25 \mathrm{~mm}$ throat diameter venturimeter with vertical (1:1) manometer is used to measure the air flow rate. The pressure drop across the test section was measured by inclined manometer having accuracy 0.05 $\mathrm{mm}$. The distilled water having specific gravity 0.9 has been used in the manometer to increase the accuracy further 


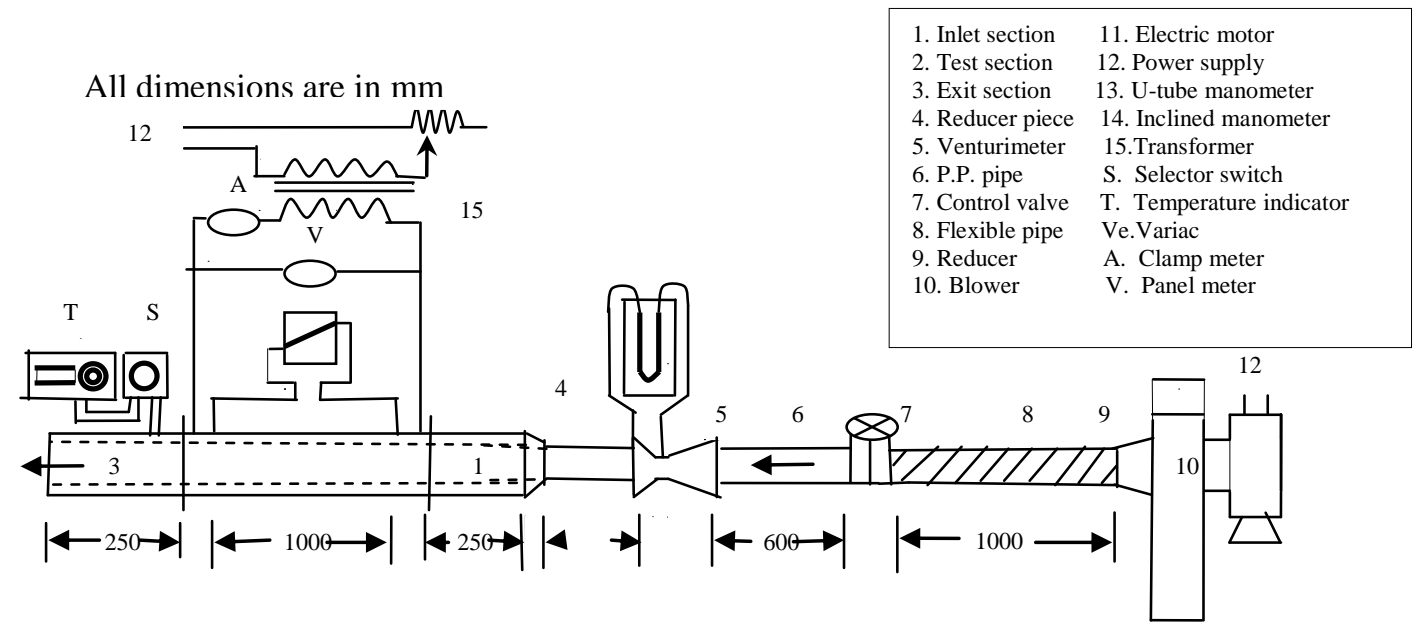

Fig. 4. Layout of Experimental Set-up

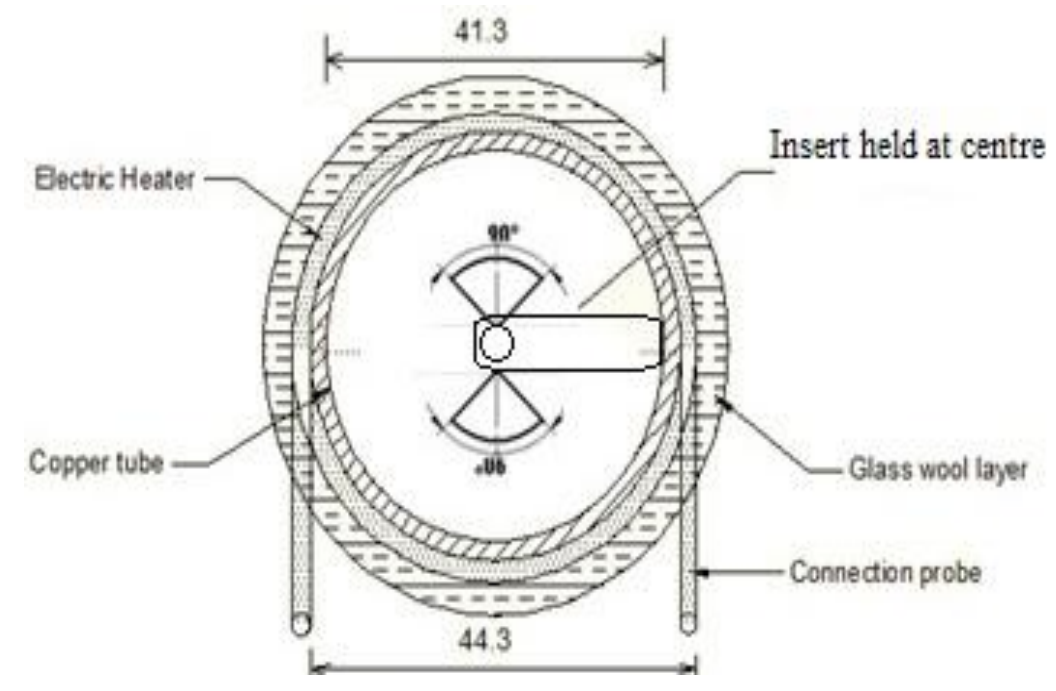

Fig. 5. Enlarged view of test cross-section

\section{B. Experimental Procedure}

The test runs to collect relevant heat transfer and flow friction data to be conducted under steady-state conditions. For different airflow rates, the system is to be allowed to attain a steady state before the data is recorded. The following parameters are to be measured.

1. Temperature of the test tube section and

2. Temperature of the air at inlet and outlet of the test section.

3. Pressure drop across the test section.

\section{Pressure difference across the venturimeter.}

The basic purpose of experimental test is to serve as a basis of comparison of results of tube with insert for the values for heat transfer and friction factor from validity test for smooth tube for obtaining thermo-hydraulic performance (Performance Evaluation Criteria)

$\left(\mathrm{Nu}_{\mathrm{r}} / \mathrm{Nu}_{\mathrm{s}}\right) /\left(\mathrm{f}_{\mathrm{r}} / \mathrm{f}_{\mathrm{s}}\right)^{1 / 3}$ of inserted geometry for the studied range of Reynolds number 5000 to 20000.

\section{RESULTS}

Some of the results obtained by different researchers for heat transfer enhancement in circular tube using different shape inserts are as follows. 
Table 1. Summary of literature review

\begin{tabular}{|c|c|c|c|c|c|}
\hline $\begin{array}{l}\text { Sr. } \\
\text { No }\end{array}$ & Author/s & Working fluid & Configuration & $\begin{array}{c}\text { Type of } \\
\text { Investigation }\end{array}$ & Observations \\
\hline 1 & $\begin{array}{l}\text { Mengna et al. } \\
\text { (19) }\end{array}$ & $\begin{array}{l}\quad \text { Air at } \\
\operatorname{Re}: 3400- \\
0000\end{array}$ & $\begin{array}{l}\text { onverging-diverging tube } \\
\text { with evenly spaced } \\
\text { wisted tapes with Space } \\
\text { ratio, } \\
\text { (s) }: 72.9-14.6 \\
\text { Space,(S) }: 1050-210 \\
\text { twist ratio, } \\
\text { (y) }: 2.22-4.72\end{array}$ & $\begin{array}{l}\text { Experimental } \\
\text { investigation in } \\
\text { a smooth } \\
\text { circular tube. }\end{array}$ & $\begin{array}{l}\text { 1) } \mathrm{Nu} / \mathrm{Nu}_{\mathrm{s}}=2.4 \& \mathrm{f} / \mathrm{f}_{\mathrm{s}}=10 \\
\text { 2) } \mathrm{Nu} / \mathrm{Nu} u_{\mathrm{cd}}=1.3 \& \mathrm{f} / \mathrm{f}_{\mathrm{cd}}=3.0 \\
\text { 3) for } \mathrm{y}=4.72, \theta=180^{\circ} \text { and } \\
\mathrm{s}=48.6 \text { resulted in efficient } \\
\text { heat transfer performance. } \\
\text { 4) The twisted-tape with } y=4.72 \text {, } \\
\theta=180^{\circ} \quad \text { and } s=48.6 \text { inserted into } \\
\quad \text { a } \mathrm{CD} \text { tube } \\
\text { has the most efficient heat transfer } \\
\text { performance of } \eta_{1}=1.211 \text { and } \\
\eta_{2}=1.148 \text { respectively at } \mathrm{Re}= \\
9000 .\end{array}$ \\
\hline 2 & $\begin{array}{l}\text { Eiamsa-ard } \\
\text { et al. } \\
\text { (20) }\end{array}$ & $\begin{array}{c}\text { Air at } \\
\operatorname{Re}: 4000- \\
20,000\end{array}$ & $\begin{array}{c}\text { Short-length twisted } \\
\text { tape insert } \\
\text { Twist ratio : } 4.0 \\
\text { Length ratio: } \\
R=0.29,0.43,0.57 \& 1.0\end{array}$ & $\begin{array}{l}\text { Experimental } \\
\text { investigation in } \\
\text { a smooth } \\
\text { circular tube. }\end{array}$ & $\begin{array}{l}\text { 1) } \mathrm{Nu} / \mathrm{Nu}_{\mathrm{s}}=1.4 \& \mathrm{f} / \mathrm{f}_{\mathrm{s}}=2.4 \\
\text { 2) } \mathrm{Nu} u_{\max } \& \mathrm{f}_{\max } \text { for } \mathrm{LR}=1 \\
\text { 3) } \eta=0.95,0.98 \text { and } 1.00 \text { for } \\
\mathrm{LR}=0.29,0.43 \text { and } 0.57\end{array}$ \\
\hline 3 & $\begin{array}{l}\text { Promvonge } \\
\text { (21) }\end{array}$ & $\begin{array}{r}\text { Air at } \\
\text { Re: } 5000- \\
5,000\end{array}$ & $\begin{array}{l}\text { Coiled wires in } \\
\text { conjunction } \\
\text { with a snail-type } \\
\text { swirl generator. }\end{array}$ & $\begin{array}{l}\text { Experimental } \\
\text { nvestigation in a } \\
\text { smooth circular } \\
\text { tube. }\end{array}$ & $\begin{array}{l}\qquad \mathrm{Nu} / \mathrm{Nu}_{\mathrm{s}}=3.4-3.9 \\
\text { The friction factor value of the snail } \\
\text { together with the square-wire is } \\
\text { found to be higher than circular } \\
\text { one by } 15-25 \% \text {. }\end{array}$ \\
\hline 4 & $\begin{array}{l}\text { Munoz } \\
\text { et al. } \\
\text { (22) }\end{array}$ & $\begin{array}{l}\text { Propylene glycol } \\
\text { Re: } 600-850\end{array}$ & $\begin{array}{l}\text { Helical wire coils fitted } \\
\text { inside a round pipe. }\end{array}$ & $\begin{array}{c}\text { Numerical } \\
\text { simulations of } \\
\text { the laminar flow } \\
\text { in pipes }\end{array}$ & $\begin{array}{l}\text { Increase of the non dimensional } \\
\text { pitch, p/d,led to decrease in friction } \\
\text { actor. }\end{array}$ \\
\hline 5 & $\begin{array}{c}\text { Kongkiatpaibon } \\
\text { et al. } \\
\text { (23) }\end{array}$ & $\begin{array}{l}\text { Air at } \\
\text { Re : } 4000- \\
20000 \\
\text { PR : } \\
6,8 \& 12\end{array}$ & $\begin{array}{c}\text { Round tube fitted with } \\
\text { circular-ring turbulators } \\
\text { Diameter Ratio: } \\
\text { DR = 0.5, } 0.6 \& 0.7 \text {. } \\
\text { Pitch length : } \\
248,496 \& 744 \mathrm{~mm} .\end{array}$ & $\begin{array}{l}\text { Experimental } \\
\text { investigation in } \\
\text { a smooth } \\
\text { circular tube. }\end{array}$ & $\begin{array}{l}\text { 1) } \mathrm{Nu} / \mathrm{Nu}_{\mathrm{s}}=2.6 \& \mathrm{f} / \mathrm{f}_{\mathrm{s}}=34 \\
\text { 2) } \eta_{\max }=1.07 \text { for Pitch ratio }=6, \mathrm{DR}= \\
7 \\
\text { 3) Heat transfer enhancement around } \\
57 \%-195 \% \text { over plain tube. }\end{array}$ \\
\hline 6 & $\begin{array}{l}\text { Promvonge } \\
\text { \& Eiamsa-ard } \\
(24)\end{array}$ & $\begin{array}{c}\text { Air at } \\
\operatorname{Re}: 6000- \\
26000\end{array}$ & $\begin{array}{l}\text { Combined conical-ring } \\
\text { and twisted tape insert } \\
\text { Twist ratio: } y=3.75 \& 7.5\end{array}$ & $\begin{array}{l}\text { Experimental } \\
\text { nvestigation in a } \\
\text { smooth circular } \\
\text { tube. }\end{array}$ & $\begin{array}{l}\text { 1) h for } y=3.75 \& 7.5 \text { are } 367 \% \text {, } \\
\& 350 \% \text { respectively. } \\
\text { 2) } h_{\max } \text { for } 316 \% \text { and } \eta \text { of } 1.16 \text { for } \\
y=3.75 \text {. }\end{array}$ \\
\hline 7 & $\begin{array}{l}\text { Fan et al. } \\
\text { (24) }\end{array}$ & $\begin{array}{c}\text { Air at } \\
\text { Re: } 10000- \\
45000\end{array}$ & $\begin{array}{l}\text { Circular tube fitted with } \\
\text { conical strip inserts with } \\
\text { slant angle } \\
a=10^{\circ}, 20^{\circ} \& 30^{\circ} \\
\text { Pitch } 30,45 \& 60 \mathrm{~mm} \text {. }\end{array}$ & Numerical study & $\begin{array}{l}\text { 1) maximal friction factor is increased } \\
\text { by } 10 \text { times ( } f=0.062-0.36) \text {, while } \\
\text { the Nusselt number by } 5 \text { times } \\
(\mathrm{Nu}=98.35-400.41) \text { over smooth } \\
\text { tube. } \\
\text { 2) PEC lies in the range of } 1.67-2.06 \text {. }\end{array}$ \\
\hline 8 & $\begin{array}{l}\text { Promvonge } \\
\text { \& Eiamsa-ard } \\
(15)\end{array}$ & $\begin{array}{l}\text { Air at } \\
\text { Re: } 8000- \\
18,000\end{array}$ & $\begin{array}{l}\text { Combined conical-nozzle } \\
\text { iserts and swirl generator } \\
\text { PR }=2.0,4.0 \text { and } 7.0\end{array}$ & $\begin{array}{l}\text { Experimental } \\
\text { nvestigation in a } \\
\text { smooth circular } \\
\text { tube. }\end{array}$ & $\begin{array}{l}\text { Conical nozzle and the snail led to } \\
\text { increase in heat transfer rate over } \\
\text { plain tube by about } 278 \% \text { and } \\
206 \% \text {, respectively. }\end{array}$ \\
\hline
\end{tabular}




\section{DISCUSSION}

In all cases studied it is common that Nusselt number ratio and friction factor increases as the Reynolds number increases. In case of twisted tapes, the results obtained by Mengna et al.(19) show that the increase in friction factor reduces as the space ratio increases. It is obvious that as the space ratio decreases, which means more twisted-tape elements are inserted in the tube, the fluid resistance increases. It is because more friction loss is induced by the secondary fluid motion, the swirl mixing and the increased friction area of twisted-tapes. Heat transfer efficiency is less for lower twist ratio (y) and higher rotation angle as it gives less turbulence. They observed that not all the cases of different space ratio and twist ratio have higher-than-unity heat transfer efficiency index in comparison with a smooth circular tube and a $C D$ tube without twisted-tape inserts. Eiamsa-ard et al. (20) observed that Heat Transfer efficiency of short length twisted tapes is lower than full length twisted tape by minimum pressure drop point of view. Highest thermal performance factor 1 is achieved with full length tape with length ratio $L R=1.0$.

In case of wire coil inserts, Gunes et al. (12) investigated experimentally for heat transfer and pressure drop in a tube with coiled wire inserts placed separately from the tube wall in turbulent flow regime and observed that the highest overall enhancement efficiency of 1.5 was obtained for the coiled wire with nondimensional pitch ratio $P / D=1$ and coil spacing

$$
\mathrm{s}=1 \mathrm{~mm} \text {. }
$$

In case of conical inserts, You et al. (16) studied thermo-hydraulic performance of laminar flow numerically and found that the average PEC value lies in the range of 2.08-2.37. Guo et al. (17) studied Effects of reducing the upwind area of conical-strip tube inserts on heat transfer and friction factor characteristics of turbulent flow and stated that the thermo-hydraulic performance factor can be enhanced by $36-61 \%$ if replacing conical-ring inserts with conical-strip inserts for turbulent flow within Re range $5000-25,000$.

\section{CONCLUSIONS}

As friction factor increases for increase in Reynolds number, twisted tape inserts are better for laminar flow than turbulent flow. Wire coil insert perform better than twisted tape in laminar flow because the coiled wire inserts which were close to the near wall region, interrupts the development of the boundary layer of the fluid flow and increases the turbulence intensity in the flow field better than the ones far from the tube wall.

Any heat transfer enhancement technique is said to good if its performance evaluation criterion (PEC) value is greater than unity. Since for turbulent flow of air researchers found higher PEC values near around 1.12.5 for conical inserts, conical inserts will be more suitable for turbulent region of flow.

\section{ACKNOWLEDGEMENT}

This work has been carried out at the IC Engine Lab, Mechanical Engineering Department, Dr. Babasaheb Ambedkar Technological University Lonere 402103 (Raigad), Maharashtra, INDIA. The authors acknowledge the University authorities for providing financial assistance \& facilities for the research.

\section{REFERENCES}

[1] Smithberg, E., \& Landis, F. (1964). Friction and Forced Convection Heat-Transfer Characteristics in Tubes with Twisted Tape Swirl Generators. ASME Journal Heat Transfer, 86, 39-48.

[2] Lopina, R. F., \& Bergles, A. E. (1969). Heat Transfer and Pressure Drop in Tape-Generated Swirl Flow of SinglePhase Water. ASME Journal Heat Transfer, 9, 434-441.

[3] Date A. W., \& Singham J. R. (1972). Numerical prediction of friction factor and heat transfer characteristics of fully developed laminar flow in tubes containing twisted tapes. ASME, 72-Heat Transfer-17.

[4] Manglik, R. K., \& Bergles, A. E. (1993). Heat transfer and pressure drop correlations for twisted-tape inserts in isothermal tubes: Part II: Transition and turbulent flows. Trans. ASME, Journal. Heat Transfer, 115,890-896.

[5] Whitham, J. M. (1896). The effects of retarders in fire tubes of steam boilers. Street Railway, 12, 374.

[6] Saha, S. K., \& Dutta, A. (2001).Thermo-hydraulic study of laminar swirl flow through a circular tube fitted with twisted tapes. I Trans. ASME, Journal. Heat Transfer, 123, 417-42.

[7] Promvonge P., Eiamsa-ard S. (2007). Heat transfer behaviors in a tube with combined conical ring and twisted tape insert. International Communications in Heat and Mass Transfer, 37, 849-859.

[8] Prasad, R. C., \& Shen, J. (1994). Performance evaluation using exergy analysis- application to wire-coil inserts in forced convection heat transfer. I - International Journal. HL'UI Mms Transfer, Vol. 37, 15, 2297-2303. 
[9] Garcia, A., Vicente, P. G., \& Viedma, A. (2005). Experimental study of heat transfer enhancement with wire coil inserts in laminar-transition-turbulent regimes at different Prandtl numbers. International Journal of Heat and Mass Transfer, 48, 4640-4651.

[10]Garcia, A., Vicente, P. G., \& Viedma, A. (2007). Enhancement of laminar and transitional flow heat transfer in tubes by means of wire coil inserts. International Journal of Heat and Mass Transfer, 50, 3176-3189.

[11]Gunes, S., Ozceyhan, V., \& Buyukalaca, O. (2010). Heat transfer enhancement in a tube with equilateral triangle cross sectioned coiled wire inserts. Experimental Thermal and Fluid Science, 34, 684-691.

[12] Gunes, S., Ozceyhan, V., \& Buyukalaca, O. (2010). The experimental investigation of heat transfer and pressure drop in a tube with coiled wire inserts placed separately from the tube wall. Applied Thermal Engineering, 30, 1719-1725.

[13]Naphon, P. (2006). Effect of coil-wire insert on heat transfer enhancement and pressure drop of the horizontal concentric tubes. International Communications in Heat and Mass Transfer, 33,753-763.

[14]Garcia, A., Solano, J. P., Vicente, P. G. and Viedma, A. (2012). The influence of artificial roughness shape on heat transfer enhancement: Corrugated tubes, dimpled tubes and wire coils. Applied Thermal Engineering, 35, 196-201.

[15]Promvonge, P., \& Eiamsa-ard S. (2006). Heat transfer enhancement in a tube with combined conical-nozzle inserts and swirl generator. Energy Conversion and Management, 47, 2867-2882.

[16]You, Y., Fan, A., Liu, W., \& Huang, S. (2012). Thermohydraulic characteristics of laminar flow in an enhanced tube with conical strip inserts. International Journal of Thermal Sciences, 61, 28-37.

[17]Guo, J., Yan, Y. X., Liu, W., Jiang, F., \& Aiwu, F. (2013). Effects of upwind area of tube inserts on heat transfer and flow resistance characteristics of turbulent flow. Experimental Thermal and Fluid Science, 48, 147-155.
[18]Muthusamy, C., Vivar, M., Skryabin, I., \& Srithar, K. (2013). Effect of conical cut-out turbulators with internal fins in a circular tube on heat transfer and friction factor. International Communications in Heat and Mass Transfer, 44, 64-68.

[19]Mengna, H., Xianhe, D., Kuo, H., \& Zhiwu, L. (2007). Compound Heat Transfer Enhancement of a ConvergingDiverging Tube with Evenly Spaced Twisted-tapes. Chinese Journal. Chemical Engineering, 15, 814-820.

[20]Eiamsa-ard S., Thianpong C., Eiamsa-ard P., \& Promvonge P. (2009). Convective heat transfer in a circular tube with short-length twisted tape insert. International Communications in Heat and Mass Transfer, 36, 365-371.

[21] Promvonge, P. (2008). Thermal enhancement in a round tube with snail entry and coiled-wire inserts. International Communications in Heat and Mass Transfer, 35, 623-629.

[22]Munoz, E. D., \& Sanmiguel, R. E. (2011). Numerical simulations of the laminar flow in pipes with wire coil inserts. Computers \& Fluids, 44, 169-177.

[23]Kongkaitpaiboon, V., Nanan, K., \& Eiamsa-ard, S. (2010). Experimental investigation of convective heat transfer and pressure loss in a round tube fitted with circular-ring turbulators. International Communications in Heat and Mass Transfer, 37, 568-574.

[24]Fan, A., Deng, J., Guo, J., \& Liu, W. (2008). A numerical study on thermo hydraulic characteristics of turbulent flow in a circular tube fitted with Conical Strip Inserts. Applied thermal engineering, 1-10.

[25]Bergles, A. E., (1985), Techniques to Augment Heat Transfer, in Handbook of Heat Transfer, editors, Rohsenow W. M., Hartnett, J. P., \& Cho, Y. I., 11.1- 11.76 , McGrawHill, New York, USA.

[26]Dewan, A., Mahanta, P., Sumithra Raju, K., \& Kumar, S.P. (2004).

[27] Review of passive heat transfer augmentation Techniques. Part A: Journal of Power and Energy, 509-27 